\title{
Assessment of effect of liming and integrated nutrient management on groundnut under acidic soil condition of West Tripura
}

\section{DIPANKAR DEY AND DIPAK NATH}

Received : 29.10.2014; Accepted : 24.05.2015

MEMBERS OF RESEARCH FORUM:
Corresponding author :
DIPAK NATH, Krishi Vigyan Kendra,
Divyodaya, West Tripura, Chebri,
KHOWAI (TRIPURA) INDIA
Email: spd020@yahoo.co.in

Co-authors : DIPANKAR DEY, Krishi Vigyan Kendra, Divyodaya, West Tripura, Chebri, KHOWAI (TRIPURA) INDIA

\begin{abstract}
Summary
Lime application and integrated nutrient management is often recommended to increase the crop productivity on acidic soils. To ascertain the individual and synergistic effects of lime, NPK and farm yard manure (FYM) application on ground nut productivity, a field experiment was undertaken on acid soils of west Tripura. Application of recommended dose of NPK (20:60:42 kg/ha of NPK) along with lime (10\% of actual LR was followed) resulted in 153 per cent yield increase over control whereas, FYM@ 5 ton/ha along with combined application of lime with recommended NPK boosted the yield improvement upto 210 per cent over control (Farmers' practice). Results of this study suggest that liming along with integrated nutrient management practices, if adopted properly, can lead to more than two-fold increase in ground nut productivity on acidic soils of West Tripura and other districts of the states of Tripura with similar soils. Post harvest soil analysis also showed improved status of organic $\mathrm{C}, \mathrm{N}$ and $\mathrm{P}$ in treated plots, but available $\mathrm{K}$ status declined emphasising the need for close monitoring and appropriate $\mathrm{K}$ application in such soils.
\end{abstract}

Key words : Liming, Integrated nutrient management, Groundnut

How to cite this article : Dey, Dipankar and Nath, Dipak (2015). Assessment of effect of liming and integrated nutrient management on groundnut under acidic soil condition of West Tripura. Asian J. Soil Sci., 10(1) : 149-153. 